\title{
Redaktørernes forord
}

Dansk Sociologi sætter med dette temanummer fokus på børn og barndom. Gennem den senere årrække har man i samfundslivet kunnet iagttage en øget og tilsyneladende vedvarende bevågenhed omkring børn, børneliv, børns livsvilkår og barndom. Selvom en væsentlig del af den samfundsmæssige opmærksomhed på børn er filtret uløseligt sammen med kommercielle interesser, er andre dele båret af andre drivkræfter. Børnekonventionen og nyere pædagogiske strømninger, der på hver deres måde bidrager til en demokratiseringsproces af barndommen, er eksempler herpå. Også sociologien og beslægtede videnskabsgrene har vist en stigende interesse for børn og barndom, en interesse, der ikke kan sættes på én og kun én fællesnævner. Gennem 1990erne har det at studere børn i egen ret dog været et gennemgående træk i mange studier. Kort sagt: Børn og barndom er for alvor kommet på dagsordenen her i begyndelsen af det 21. århundrede.

Sådan har det måske været længe, eller i det mindste længere, end man umiddelbart tror. Ser man tilbage på det forrige århundrede har der i perioder gennem det 20. århundrede været personer og humane kræfter i samfundet, som var stærkt optaget af børn og barndom. Man kan henvise til Ellen Key's prognostisering af "barnets århundrede" omkring 1900, til Peter Sabroes kamp for at forbedre børns forhold på samme tid, til Sofie Rifbjergs engagement i børn med begrænsede evner, til de mange engagerede pædagogers bekymringer for børns opvækst og opdragelse i tiden efter 1 . verdenskrigs rædsler, til interessen for børns levevilkår i forbindelse med velfærdsstatens tilblivelse gennem 2 . halvdel af det 20. århundrede, eller til den fri børneopdragelse i forbindelse med de anti-autoritære strømninger i 1960erne og -70erne. Og sådan kan man blive ved.

Det nye er derfor ikke, at børn og barndom er i fokus, men snarere de måder, hvorpå børn og barndom nu optager de professionelle - herunder også sociologerne. Måder og tilgange til at forske i og beskæftige sig med børn på har tilsyneladende fået en ny drejning gennem de seneste 10-15 år. Udtrykt med en vis forsigtighed kan man tale om et "TURN" i børne- og barndomsforskningen. Det kommer til udtryk gennem det børnesyn, der ligger bag en stigende del af forskningen, som tilskriver barndommen selvstændig begrebslig status og gør børn til sociale aktører. Det fremgår af de spørgsmål og emner, som sociologer og andre professionelle, er optagede af. Hvor forskningsperspektivet tidligere ofte omhandlede de langsigtede konsekvenser og effekter af forskellige barndomme, interesserer man sig i dag også for, hvordan det aktuelle børneliv tager sig ud. Sidst, men ikke mindst ses drejningen afspejlet i de metoder og tilgange, der bliver anvendt. Det såkaldte børneperspektiv står således centralt i mange empirisk baserede studier om børn og barndom.

I dag behøver børneforskere og barndomssociologer ikke at bruge så mange kræfter som før på at argumentere for, at børn har evner og kunnen, og er med til 
at skabe deres eget liv, at børn i forskningsmæssige sammenhænge kan anvendes som informanter eller respondenter, og at børn og barndom er værd at studere $i$ egen ret. Det er efterhånden ved at blive en selvfølge, selv om der fortsat er modstridende forskningsinteresser, ikke mindst når man bevæger sig uden-for børneforskningens snævrere kredse. På sin vis kan man sige, at i takt med, at der fødes færre børn, bliver de "fă", som er tilbage, taget mere alvorligt og studeret mere minutiøst. Men risikoen for tilbageslag er hele tiden til stede. Trods alle demokratiseringstendenser er børn en meget lidt magtfuld samfundsmæssig gruppe uden samme stemmekraft og ytringsmuligheder som voksne, og også den sociologiske forskning står over for udfordringer med at inkorporere disse ytringer, ikke mindst fra de børn, der falder ved siden af den "normale" barndoms spor.

Inden for sociologien har den omtalte drejning markeret sig gennem forskningsprojekter og ny viden om børn og barndom, og man kan i dag tale om eksistensen af en barndomssociologi. Termer som barndomsteori, barndoms-sociologi eller bare "børn" og "barndom" optræder stadigt hyppigere i de forskningsbaserede publikationer og i forbindelse med de sociologiske kongresser. Om disse tegn er midlertidige fænomener og tidstypiske spor i en større samfundsmæssig udvikling, eller om tendenserne vil konsolidere sig, er vanskeligt at svare på. Historien bærer vidnesbyrd om, at "barndommen" og synet på børn fortløbende rekonstrueres i takt med, at børns materielle, sociale og kulturelle vilkår forandres.

Artiklerne i dette temanummer af Dansk Sociologi byder på forskellige smagsprøver på noget af det, der for tiden rører sig og reflekteres i det barndomssociologiske forskningsfelt:

Nøglespørgsmålet om, hvordan materialitet og repræsentation relaterer til hinanden, aktualiseres i Alan Prouts teoretiske artikel om barndommes kroppe. Problemstillingen er relevant, for barndomssociologien har ikke just været afklaret omkring forholdet mellem natur og kultur. Artiklen rejser en række kritiske spørgsmål til de forståelsesformer, der baserer sig på socialkonstruktivismen og peger bl.a. på, hvordan det sociale livs materialitet står i fare for at blive ekskluderet. Samtidig har barndomssociologien med sit projekt om at forstå børn som sociale aktører netop gjort opmærksom på betydningen af børns kroppe og på, hvordan disse agerer, opleves og konstrueres. Prout finder et potentiale i aktør-netværks-teorien, da denne undersøgelseslinie kan udrede nogle af de måder, hvorpå børns kroppe er knyttet sammen med andre aspekter af de materielle omgivelser.

Jens Qvortrups artikel reflekterer over problemstillingen om børns skolearbejde, et område, som Qvortrup mener, er forskningsmæssigt og politisk forsømt. Konsekvensen er, at der i dag ikke eksisterer en ordentlig og accepterende anerkendelse af det (skole)arbejde, børn vitterlig udfører. Selvom tendensen i moderne samfund er kendetegnet ved, at børn betragtes som nytteløse og som en økonomisk byrde, burde børns skolearbejde snarere betragtes som en integreret del af den samfundsmæssige økonomi, tilsvarende børns bidrag i tidligere tiders husholdningsøkonomi, hvor alle økonomiske processer fandt sted i ethvert "oikos". Hvad der i nutiden forhindrer den samme direkte og gennemskuelige forbindelse mellem produktion og reproduktion, som fandtes i fortidens "oikos", er alle de differentieringer og reguleringer, der kendetegner den skattefinansierede velfærdsstat, og som bidrager til at skjule børns skolegang som del af den samfundsmæssige arbejdsdeling, argumenteres der. 
"Børns ret" og "Barnets tarv" er centrale figurer i den samfundspolitiske debat og retningsgivende for, hvordan socialforvaltninger og det familieretlige system skal agere i sager, hvori der er børn involveret. Men hvad dækker begreberne over? Med børneforsorgsarbejdet som eksempelmateriale sætter Tine Egelund de to figurer under kritisk sociologisk lup. Egelund viser, at hverken konventionen om barnets rettigheder, serviceloven eller børnevelfærdsforskningen, der hver for sig leverer bidrag til en konstruktion af tarvbegrebet, er så eksplicit, præcis eller entydig, at der ydes klare standarder for, hvad børns tarv vil sige. De sagsbehandlere, der skønner over barnets tarv efterlades dermed i et tomrum, og det kan medføre, at skønnet personliggøres med store individuelle forskelle til følge, samt at andre hensyn end hensynet til barnets bedste kommer til at dominere sagsarbejdet.

Pia Haudrup Christensens artikel problematiserer, at svaret skulle være mere tid, når spørgsmålet rejses om, hvordan børnefamilien balancerer mellem et godt arbejdsliv og et sundt familieliv. Hvad der er godt for nutidens børn og deres familier har hidtil været baseret på de opfattelser, som voksne informanter har ladet komme til udtryk i studier om $\mathrm{fx}$ tidspuslespillet. Artiklen er et eksempel på, hvordan barndomssociologiens social-aktør-perspektiv også har metodologiske konsekvenser. Ved at inddrage børn som informanter i forskningen og lytte til deres udsagn om tid og tidsforbrug må Christensen i sin drøftelse modificere begrebet kvalitetstid til fordel for en mere nuanceret tidsforståelse.

I temanummerets review-artikel giver Jan Kampmann et overblik over det barndomssociologiske felt, som det har udviklet sig såvel internationalt som herhjemme. Artiklen problematiserer også barndomssociologiens udviklingshistorie, der er længere, end man umiddelbart tror, ligesom den peger på nogle af de svage punkter, der opstår, når et nyt felt kridtes op og søger efter legitimitet. Det er svagheder, som sjældent holder i længden, når først "spillet" er i gang, og som $i$ alt fald tvinger den nu etablerede barndomssociologi til at gå ind i en selvkritisk refleksionsproces.

Jens Rasmussen har skrevet dette nummers kronik, som sætter forholdet mellem opdragelse og undervisning til diskussion. Kronikkens afsæt er de beklagelser, skolelærere adresserer til hjemmene, når forældre bebrejdes, at eleverne i dag ikke er opdraget sådan, at de er til at undervise. Rasmussen demonstrerer, at der langt fra er tale om en ny problemstilling, og argumenterer herfra, at den opdragelse, som finder sted i familiens intimsystem, aldrig ville kunne indfri skolesystemets forventninger om motiverede, videbegærlige og disciplinerede elever, fordi de to systemer er baseret på forskellige rationaler. Skolen får ikke løst sit problem ved at afvise at opdrage eller ved at henvise det til andet sted i samfundet; den må selv påtage sig at opdrage børnene til elever.

Alt i alt kan de forskellige artikler ses som bidrag til og indblik i centrale emner indenfor det brede barndomssociologiske område. Som sådan illustrerer artikelbidragene, når man ser dem samlet, feltets bredde og den indbyrdes varians og forskellighed, som området er kendetegnet ved. Temanummeret rundes af med en række anmeldelser af udenlandske, men især danske bøger og undersøgelser, som yderligere bidrager til at give et - langt fra udtømmende - indtryk af, hvad der rører sig på det aktuelle børneog barndomsforskningsfelt i forskellige miljøer.

Mai Heide Ottosen og Kim Rasmussen 